\title{
PAKISTAN IN 2008
}

\author{
Moving beyond Musharraf
}

\section{Matthew J. Nelson}

\begin{abstract}
Following the assassination of Benazir Bhutto in December 2007 and national elections in February 2008, Pakistan struggled to distance itself from the discredited military regime of President (General) Pervez Musharraf. Competition between the Pakistan People's Party (PPP), once led by Benazir Bhutto and subsequently by her widower Asif Ali Zardari, and the Pakistan Muslim League (PML-N) led by Nawaz Sharif, however, threatened to thwart the cause of political stability in Pakistan.
\end{abstract}

Keywords: Pakistan, party politics, Musharraf, judiciary, FATA

\section{Introduction}

Following the assassination of former Prime Minister Benazir Bhutto on December 27, 2007, national elections originally scheduled for January 8, 2008, were postponed until February 18. These elections and their aftermath defined a year of extraordinary political hope, bitter disappointment, and growing instability in Pakistan. The February 2008 elections dealt then-President Pervez Musharraf a crushing defeat and the party of the late Benazir Bhutto - the Pakistan People's Party (PPP) - emerged as the largest seat holder in the National Assembly, riding a wave of sympathy and anti-incumbency tinged with strong hints of anti-Americanism critical of the close relationship between Musharraf and U.S. President George W. Bush. The mood in Pakistan after these elections was jubilant and optimistic. Many felt that, after more than eight years under Musharraf,

Matthew J. Nelson is Lecturer in Politics at the School of Oriental and African Studies (SOAS), University of London. Email: <mn6@soas.ac.uk>.

Asian Survey, Vol. 49, Issue 1, pp. 16-27, ISSN 0004-4687, electronic ISSN 1533-838X. (C 2009 by The Regents of the University of California. All rights reserved. Please direct all requests for permission to photocopy or reproduce article content through the University of California Press's Rights and Permissions website, at http://www.ucpressjournals.com/reprintInfo.asp. DOI: AS.2009.49.1.16. 
the tide had finally turned away from "dictatorship" toward a fully elected "democracy."

Short of an outright majority in Islamabad, the PPP sought to construct a coalition government with several of its chief rivals, including the Nawaz Sharif faction of the Pakistan Muslim League (PML-N), which performed well in Punjab; the Muttahida Quami Movement (MQM, United National Movement), which continued to play an important role in the urban areas of Sindh Province; the Awami National Party (ANP, People's National Party), which achieved a plurality in the Northwest Frontier Province (NWFP); and the Fazlur Rahman faction of the religiously conservative but politically savvy Jamiat-e-Ulema-e-Islam (JUI-F, Party of the Ulema of Islam). Indeed, some in Pakistan even dared to imagine the emergence of a grand coalition led by the PPP with a strong two-thirds majority in both the National Assembly and the Senate that would give the incoming government sufficient political strength to press for the outright impeachment of Musharraf, the passage of constitutional reforms designed to strengthen the judiciary, and the possible abolishment of a notorious constitutional feature known as Clause 58-2(b), which empowered the president to dissolve the legislature.

Yet, these hopes were quickly dashed when signs of discord emerged within the incoming ruling coalition even before it could be formally sworn in on March 17. Sharif and his party, the PML-N, tried to expand their influence within the incoming government by demanding a growing list of concessions from the PPP, but the latter, under its new leader Asif Ali Zardari (Bhutto's widower), either refused or failed to accommodate these demands. In many ways, the trajectory of Pakistani politics in 2008 can be read in two parts beginning with the formation of a new ruling coalition led by the PPP in February and then subsequent dissention within this ruling coalition after Sharif began expressing public opposition to Zardari's continuation of many policies once embraced by Musharraf — including, most importantly, his close relationship with the U.S. in the so-called "war on terror" both within Pakistan and along the Pakistan-Afghanistan border.

Sharif's pattern of opposition resonated on two levels. The first focused on efforts to restore Iftikhar Mohammad Chaudhry - the chief justice of Pakistan's Supreme Court - after he was suspended in March 2007, then reinstated in July following nationwide protests, and finally dismissed again along with more than 60 other Supreme Court and provincial high court judges in November after Musharraf declared a nationwide "state of emergency." The second dealt with the rapidly escalating unrest along the Pakistan-Afghanistan border particularly, but not exclusively, in an area known as the Federally Administrated Tribal Areas (FATA), as well as growing U.S. pressure on Pakistan to address this unrest through 
aggressive military action targeting affiliates of al-Qaeda and the Taliban. ${ }^{1}$ Zardari progressively alienated the general Pakistani public through 2008 by resisting the restoration of Chief Justice Chaudhry and by permitting greater U.S. involvement in FATA. Zardari, in effect, became closely associated with the positions once embraced by Musharraf. Sharif, on the other hand, sought to capitalize on this growing sense of public frustration by distancing himself from these positions. Sharif, in fact, openly supported the restoration of Chaudhry and opposed U.S. military action in FATA, including missile attacks launched from unmanned Predator drones.

\section{Restoring Democracy? Party Politics, Civil Society, and a Weak Judiciary}

In 2007, lawyers throughout Pakistan rose up to resist the dismissal of the Pakistan Supreme Court's chief justice. Their movement was "antiMusharraf" but otherwise non-partisan at first. In fact, the lawyers initially focused on defending Chaudhry's efforts to prosecute senior members of Musharraf's regime for corruption and Chaudhry's suspected inclination to hear a series of cases challenging the constitutionality of Musharraf simultaneously holding the positions of president and chief of the army staff.

This pattern of anti-Musharraf non-partisanship, however, slowly began to change during the final months of 2007 when, under pressure from his patrons in Washington, Musharraf appeared to reach a "return-to-democracy" agreement with Bhutto. According to this agreement, known as the National Reconciliation Ordinance (NRO), Musharraf agreed to resign as chief of the army staff but retain his position as a civilian president. For her part, Bhutto agreed to return from exile in Dubai and London; participate in the national elections originally scheduled for January 2008; and work with Musharraf, the army, and the U.S. to support the global "war on terror" in exchange for having the corruption cases pending against her and her husband dropped. In the wake of this agreement, however, some of the anti-Musharraf lawyers - particularly those who maintained some connection with the PML-N) - felt that Bhutto had capitulated to the terms of an enduring dictatorship in a short-sighted effort to advance her own political ambitions. And, in their frustration, these lawyers began shifting their support away from Bhutto to the party of her chief rival, Nawaz Sharif.

1. FATA comprises seven areas, or "agencies," administered directly (albeit loosely) by the central government in Islamabad. The structure of FATA's administration is unlike other districts and provinces in Pakistan. For details, see Naveed Ahmad Shinwari, Understanding FATA (Peshawar: Community Appraisal and Motivation Program, 2008), pp. 12-21. 
As the election approached, the political landscape became sharply divided between those in Pakistan who wished to construct a "transitional" government with enduring ties to Musharraf and those who sought to "transform" the system by rejecting him altogether. The former included the PPP, the pro-Musharraf PML-Q (Pakistan Muslim League, "Quaid-eAzam" faction), and the regional MQM. Those seeking "transformation" included the PML-N and two major parties within a prominent multiparty religious alliance known as the Muttahida Majlis-e-Amal (MMA, United Council of Action) - namely, the JUI-F and the Jama'at-e-Islami (the Party of Islam). The Jama'at-e-Islami argued for a boycott of the elections, but, as the elections drew closer, the PML-N refused to stand idly by and watch while the PPP seized power. In December 2007, the JUI-F followed suit. In fact, when the elections finally took place in February 2008, the "transformationist" lawyers and an assortment of smaller parties like Imran Khan's Tehreek-e-Insaaf (Pakistan Movement for Justice) found themselves boycotting the elections without the support of any major party except the Jama'at-e-Islami.

The election itself suffered from a rather low turnout, owing largely to pre-poll violence in the NWFP and concerns about pre-poll rigging in favor of the pro-Musharraf PML-Q. Nevertheless, the election results were widely accepted by the Pakistani public; international election observers declared that the voting was "reasonably competitive." In fact, the results amounted to a bitter referendum against Musharraf, not only owing to his dismissal of Chief Justice Chaudhry but also because of the extensive damage done to the Lal Masjid (Red Mosque) in Islamabad when security forces stormed it in July 2007 and because of his declaration of a state of emergency in Pakistan in November of that year.

Before the elections, U.S. officials had hoped that the results would lead to the formation of a "friendly" coalition government composed of the PPP and the pro-Musharraf PML-Q, but the PPP rejected the PML-Q shortly after the elections. Instead, it sought to construct an alternative coalition consisting of itself (with 124 out of 340 National Assembly seats), the PML-N (with 91 seats), and several smaller regional parties. In fact, many believed that the PPP might actually succeed in constructing a two-thirds majority across both the National Assembly and the Senate with support from the MQM with 25 seats, the ANP with 13 seats, the JUI-F with 7 seats, and an assorted array of independents and affiliates. This would have allowed the government to formally impeach Musharraf, but this two-thirds majority failed to materialize because of the enduring dominance of the pro-Musharraf PML-Q in the Senate that had already been elected - albeit indirectly - by existing members of the provincial assemblies earlier in March 2006. 
Much to the dismay of the Pakistani electorate, the Bush administration continued to support a central role for Musharraf in the new government even after the devastating defeat of the PML-Q. In a similar vein, Zardari's victorious PPP also did not appear especially keen to force Musharraf out of his role as president after the elections, nor did it seek to distance itself from the policies of the U.S. On the contrary, Zardari, in fact, consistently maintained after the election that he would continue to work with Musharraf, the Pakistani army, and the U.S., thus leaving the general public feeling somewhat drawn-and-quartered between their support for the party of the late Benazir Bhutto and their frustration with the policies of the previous eight years.

The most important issue was the willingness of the PPP to join Musharraf in refusing to restore Chief Justice Chaudhary. This irked Sharif who, before agreeing to join the PPP-led coalition, had compelled the PPP to agree to a specific deadline for Chaudhary's restoration. A deadline of March 8, 2008, had been set, but the modalities for this "restoration" were never clearly specified. In the wake of the elections, it became increasingly clear that both Musharraf and Zardari shared an interest in keeping Chief Justice Chaudhary off the bench. Musharraf feared that Chaudhary would invalidate his re-election as president because this had occurred before Musharraf resigned as chief of the army staff in 2007, thus potentially violating rules that prohibit the president from holding two positions at the same time. For his part, Zardari feared that Chaudhary would reverse Musharraf's earlier decision to set aside numerous corruption cases pending against him and his slain wife as agreed to in the NRO, thus effectively sending Zardari back to jail.

Chaudhry attempted to reassure Zardari shortly after the elections with a personal visit to congratulate him on his political victory, but Zardari did not embrace this overture. Instead, Zardari appeared to accept the chief justice appointed by Musharraf to replace Chaudhry-a long-time resident of Sindh, like Zardari, by the name of Abdul Hameed Dogar. Needless to say, this willingness to accept Chief Justice Dogar frustrated the "transformationist" lawyers - particularly those affiliated with the PML-N-and Sharif kept this sense of frustration alive to great political effect. In fact, the PML-N seized upon the PPP's failure to restore the chief justice to sustain its vigorous campaign of criticizing Musharraf's legacy.

For several months after the February 2008 elections, the PML-N sought to articulate its frustration from within the coalition Cabinet. But, the PML-N withdrew its ministers in May while continuing to offer certain types of "cooperation" to the PPP-led government in an attempt to bolster its relative bargaining power. Yet, neither strategy had much effect and the PML-N formally resigned from the government altogether in August. This 
forced the PPP to scramble for the support of several smaller parties to retain a majority in the National Assembly. In other words, the grand coalition that had emerged in the wake of the February elections essentially collapsed within just six months. What began as a movement led by "transformationist" lawyers mildly supportive of the PPP in 2007 was, by the end of 2008, a movement of "transformationist" lawyers largely supportive of the PML-N. The same lawyers who had previously demanded Musharraf's replacement in 2007 were demanding the ouster of Zardari by late 2008, largely owing to the lack of substantive political change after the election.

\section{Defeating Terrorism? Party Politics, FATA, and the "War on Terror"}

As the grand coalition led by the PPP began to unravel, the fate and direction of the "transformationist" opposition led by Sharif was tied, not only to the lawyers movement, but also increasingly to the provincial politics of the NWFP and FATA, and to the prosecution of America's global "war on terror." In the wake of the February elections, politics in the NWFP and FATA shifted dramatically because the coalition of religious parties known as the MMA - already under considerable stress after the JUI-F split from the Jama'at-e-Islami over the election boycott — was defeated by the regional, secular, Pashtun-nationalist ANP. Some argued that this electoral outcome reflected a move away from the "religious" orientation of the MMA and toward greater support for the U.S.-led "war on terror," but an alternative reading suggests that the MMA may have been rejected because, for many years, it had remained a willing participant in the U.S.supported Musharraf-led government. Indeed, for many of the voters who cast their votes in February, a ballot cast against Musharraf was a vote against the U.S. Yet, a ballot cast against Musharraf in the NWFP and FATA was also a ballot cast against the flexibly pro-Musharraf MMA. In fact, throughout its period in power, Musharraf's government had maintained close ties to the U.S. even while it sustained a close relationship with MMA-affiliated religious parties like the JUI-F, long associated with the Taliban. For Musharraf, such complex loyalties were in keeping with a clear distinction between measured support for the U.S.-sponsored fight against "foreign" agents associated with al-Qaeda while, on the other hand, being reluctant to fight against "local" tribesmen often affiliated with the Taliban. Musharraf also wished to preserve a strategic foothold, within Afghanistan, via the Taliban.

Both the PPP and the newly victorious NWFP-based ANP insisted that since $9 / 11$, Musharraf had erred in attempting to impose a purely military solution on the growing Taliban insurgency in FATA. Seeking to devise an alternative, they argued that a purely military option should be set aside in 
favor of a political approach grounded in dialogue, diplomacy, and deal making. This alternative was, somewhat ironically, attractive to the JUI-F as well. Under the nimble leadership of Fazlur Rahman, the JUI-F actually abandoned Musharraf after the February elections in favor of the PPP and its former provincial rival - the ANP - in Islamabad. In fact, with its close ties to the Taliban, the JUI-F insisted that it was particularly eager to support the new ruling coalition in its efforts to temper the military presence of the U.S. along the border with Afghanistan, especially in FATA.

Musharraf's selective pursuit of al-Qaeda affiliates and his initial refusal to aggressively crack down on the Taliban angered the U.S., which found itself struggling to counter the Taliban on the Afghan side of the border while Taliban fighters were provided with a safe haven on the Pakistani side. Yet, as the Taliban began targeting Pakistan itself, Musharraf started to yield to pressure from the U.S. by adjusting the terms of several strategic relationships. First, he negotiated arrangements with a group of severely weakened tribal elders in FATA (maliks), who agreed to monitor the Afghan-Pakistani border and restrict cross-border movement in exchange for assurances that the Pakistani army would not attack their villages while searching for "foreign" al-Qaeda fighters. Second, he deployed the Pakistani army to regain control of places where local maliks were unable or unwilling to maintain control, primarily owing to a campaign of terror in which the Taliban captured and slaughtered hundreds of elders accused of supporting Musharraf and the Americans.

The Americans, for their part, were eager to support any efforts to crack down on the Taliban on either side of the border. Yet, even within this new approach constructed by Musharraf, many observers perceived reluctance on the part of the Pakistani leadership to completely abandon its established military doctrine vis-à-vis the "local" Taliban. For this reason, American commanders insisted with increasing frequency that U.S. troops should be allowed to pursue their military goals within Pakistan itself more directly. These American commanders initially relied on unmanned Predator drones to attack suspected al-Qaeda and Taliban positions. But as the bombs dropped by these drones hit more and more civilians while missing al-Qaeda or Taliban targets, the Americans began suspecting that their efforts were being thwarted by Pakistan's premier intelligence agency, the Inter-Services Intelligence (ISI), well known for its close ties to the Taliban. Partially for this reason, the U.S. began in July to act more frequently on its own. President Bush, in fact, approved a secret authorization to allow clandestine U.S.-led ground incursions in Pakistan, including a controversial ground operation during the first week of September. ${ }^{2}$ By

2. Eric Schmitt and Mark Mazzetti, "Secret Order Lets U.S. Raid Al Qaeda," New York Times, November 10, 2008. 
the end of 2008, however, reports of civilian deaths caused by U.S. military operations within Pakistan began to fill newspaper headlines, and public frustration throughout the country began to explode. Indeed, one of the most important features of the political landscape in Pakistan, throughout 2008, arose from the difficulty of building a strong national consensus to address the problem of religious terrorism in Pakistan. In poll after poll, the Taliban were described as being a "marginal" threat to Pakistan in comparison to the U.S. ${ }^{3}$

Throughout FATA, as well as certain non-FATA areas along the border, this sense of frustration with both local political elites and their American patrons provided ambitious warlords with ample public support. For instance, a history of tribal competition in South Waziristan involving the Wazir and Mehsud tribes saw the strength of the latter expand significantly under the leadership of Baitullah Mehsud. Mehsud's power grew rapidly in the wake of his efforts to distance himself from local maliks, supported by the government, in favor of a Taliban-affiliated group known as the Tehreek-e-Taliban (Taliban Alliance), which itself was allied with the Afghan Taliban commander Mullah Omar. Similar dynamics were also seen in the Khyber Agency, the Bajaur Agency, and the Swat Valley, where local leaders affiliated with the Taliban and their ideology gained power over their local factional rivals.

Throughout this period, U.S. and Pakistani efforts to tackle the Taliban militarily remained deeply unpopular within the general population in Pakistan. Poorly targeted air strikes causing extensive civilian casualties became commonplace. For example, the U.N. and other agencies estimated that the total number of people displaced by the fighting in Bajaur alone was more than 300,000 by October. When President Zardari called a special closed session of the National Assembly to provide the army with an opportunity to bring local politicians - and, in due course, the general public - on board, few politicians bothered to attend. Instead, the PML-N, the JUI-F, and the "transformationist" Jama'at-e-Islami argued, in a direct challenge to Zardari and the army, that the Taliban should have received a parallel opportunity to present its own side of the story.

For its part, the general public in Pakistan became increasingly concerned by late 2008 that the U.S. military was prepared to cross over the Afghan-Pakistani border to engage the Taliban within FATA and the other border regions. This is a concern that U.S. President-elect Barack Obama did little to discourage throughout his election campaign. In fact, Pakistani

3. For details, see the public opinion poll conducted by the New America Foundation and Terror Free Tomorrow: The Center for Public Opinion, May and June 2008, in Pakistan, available at $<$ http://www.newamerica.net/files/PakistanPoll-summary.pdf $>$. 
soldiers began firing on U.S. helicopters as early as September in their attempt to push the Americans away from the Pakistan side of the Durand Line separating Afghanistan and Pakistan. As the year drew to a close, local vigilante patrols known as tribal lashkars, who were supported by the ruling ANP provincial government in Peshawar to maintain its traditional political base among the Pashtun tribes of the NWFP, were increasingly being armed with Chinese-made AK-47s to fight off the Taliban in their own areas. The formation of these lashkars was regarded as an entirely new phase in counterinsurgency efforts against the Taliban, but the efficacy of this new approach seemed highly questionable because the lashkar targets also included the Americans as well as many local tribal rivals.

\section{Economic Instability and the Onset of Global Recession}

During the latter half of 2008, the deteriorating economic situation throughout the world only compounded Pakistan's worsening security situation. Indeed, many observers wondered how an imploding economy characterized by rapidly rising prices, accelerating unemployment, and a plummeting Pakistani rupee would affect the stability of Zardari's government. Under Musharraf, economic growth had been unusually swift but also quite uneven. After 9/11, for instance, Pakistan benefited from more than $\$ 10$ billion in U.S. assistance to support its global "war on terror" but less than $10 \%$ of this was allocated for social and economic development. The new middle classes in Pakistan encountered an expanding range of servicebased employment opportunities in urban areas, but little changed for the rural majority. During the second half of 2008, economic expansion came to a virtual standstill.

After the February elections, the Karachi Stock Exchange (KSE) experienced a noticeable bounce. This occurred even though stock prices in other parts of the world saw sharp declines in January and February, caused by the ripple effects of the emerging "credit crunch" in the U.S. There was a brief surge on the KSE in April but, after this, stock prices fell sharply and, by July, panicked investors were seen pelting the KSE building with stones. By October, worried analysts noted that the KSE had lost almost half of its value.

At the same time, the value of the rupee fell more than $25 \%$, pushing prices for essential imports such as oil to record levels through the summer. During the second half of 2008, Pakistan also saw its annual rate of inflation rise to more than $25 \%$ before falling back again in November and December. In Peshawar, for instance, emergency supplies of wheat flour had to be brought in from Punjab after market prices rose from Rs 515 
(\$6.75) per 20 kilograms of wheat in August to as much as Rs 710 (\$9.50) for consumers by the middle of October. The Islami Jamiat-e-Tulaba (Party of Islamic Students) - the student wing of the Jama'at-e-Islami-blamed the provincial ANP government and the PPP-led central government in Islamabad for these rapidly rising prices, not the global credit crisis. The students argued that the defeat of the MMA at the hands of the ANP and the PPP had exacerbated the economic plight of ordinary Pashtuns throughout the NWFP.

With a severe recession unfolding throughout the world, remittances sent by migrant Pakistani laborers working abroad dropped precipitously. The rate of unemployment both domestically and internationally also rose dramatically. The ongoing crisis of political instability in Pakistan raised the cost of insuring Pakistani government bonds against the risk of default to one of the world's highest rates. Indeed, even as Pakistan appealed for international assistance to help prevent an accelerating economic meltdown, it found that it would have to pay an extremely high price for the privilege of securing any further loans. By autumn, Pakistan's foreign currency coffers had been depleted to such an extent-from nearly $\$ 14$ billion in November 2007 to just $\$ 5.5$ billion in October 2008 - that officials were forced to request special assistance from the International Monetary Fund (IMF). Discussing an emergency loan of $\$ 5$ billion to $\$ 7$ billion to avoid an immediate balance-of-payments crisis-including defaulting on its foreign debt - the government said that ultimately it would likely need more than $\$ 10$ billion- $\$ 15$ billion. Many analysts were concerned that the conditions attached to an IMF loan would force the government to reduce its spending, thus exacerbating public discontent. Others feared that the public-atlarge in Pakistan would simply crack under the pressure of this rapidly contracting fiscal environment. All wondered about the threshold beyond which Zardari's government would begin to possibly wobble, buckle, and fold. In fact, the emergence of a last-minute rescue package from the IMF did little to calm the nerves of economists and politicians alike.

\section{Conclusion}

Throughout 2008, the central front of the U.S.-led "war on terror" appeared to shift away from the war in Iraq to the border between Afghanistan and Pakistan. Senior leaders of the Pakistani army struggled, with varying degrees of success, to shift their attention away from the force's traditional focus on preparing for a conventional war with India toward the growing insurgency within Pakistan itself. Yet, this rather dramatic shift was made even more difficult by a pattern of persistent recalcitrance among a small portion of the army's rank-and-file, which opted to surrender to the 
Taliban (for example, in South Waziristan) in order to avoid engaging their Pashtun "brothers" in battle. In addition, both the military leadership and its rank-and-file were reluctant to give up the reins of economic and political power in favor of an elected civilian government so clearly divided by short-term partisan concerns.

Indeed, it would hardly be an exaggeration to say that the whole of Pakistan was engaged in fighting two major battles throughout 2008. The first positioned the Pakistani Taliban against the Pakistani army in FATA; the second pitted the political "transitionists" against the political "transformationists" in Islamabad. After the defeat of the pro-Musharraf PML-Q in February, many viewed the Zardari-led civilian government as being a cathartic departure from more than eight years of some form of military dictatorship. Yet, by the end of 2008, many of the most important features of the Musharraf regime appeared to remain firmly in place. In fact, many Pakistanis began to feel that the most important feature of the domestic political landscape was no longer Musharraf but rather the enduring influence of the U.S. - a pattern that seemed to shift, almost seamlessly, from Musharraf during the first part of the year to Zardari thereafter.

\section{Postscript}

On November 26 through 29, a group of 10 terrorists attacked several different locations in Mumbai, India, including a large railway station, two five-star hotels, and a Jewish community center, killing more than 170 persons. The affiliations of the terrorists were not immediately apparent, but initial accusations focused on well-known terrorist groups like Lashkar-eTaiba (LT, Army of the Pure), based in Pakistan. In fact, the U.N. Security Council unanimously condemned the parent organization of LT - namely, Jama'at-ud-Dawa (JD, Party of Religious Invitation) on December 11. This prompted Pakistani officials to raid JD offices throughout Pakistan.

Many observers surmised that the attack was orchestrated by militants based in Pakistan in an effort to draw attention away from the ongoing struggle in FATA - in effect, a calculated attempt to shift the firepower of the Pakistani army away from a sustained assault on militants operating along the border with Afghanistan toward Pakistan's traditional enemy, namely, India. This assessment appeared to have some merit as a small number of Pakistani army troops were transferred away from the "western" to the "eastern" front in mid-December. Intensive diplomatic efforts around the world, however, quickly reduced the threat of war, shifting the focus of attention back to the need for a coordinated transnational police investigation into the attacks in Mumbai and a multilateral response to terrorism throughout South Asia. 
This effort to stress the need for a coordinated multilateral response was complicated, however, by a belligerent media response to the attack, on both sides of the border. Indeed, the extreme fragility of ruling coalitions in both countries made it very difficult domestically for Prime Minister Manmohan Singh of India and President Zardari of Pakistan to promote politically unpopular forms of cooperation. As 2008 came to an end, intensive international pressure appeared to ensure that expanding cross-national cooperation would continue to have the upper hand in both countries' response to these terrorist attacks. 